\title{
PENGEMBANGAN PERANGKAT PEMBELAJARAN UNTUK MEREDUKSI MISKONSEPSI SISWA PADA MATERI RANGKAIAN LISTRIK DENGAN SCIENTIFIC APPROACH
}

\author{
Mukhlis Hidayatulloh, Farisa Humairoh, Ulfa Wachidah, Dwi Ayu Iswati, dan Suliyanah \\ Jurusan Fisika FMIPA Universitas Negeri Surabaya \\ email : hidayatullohmukhlis027@gmail.com
}

\begin{abstract}
Abstrak
Studi pendahuluan menemukan bahwa banyak miskonsepsi yang terjadi pada materi rangkaian listrik pada topik semakin jauh dari kutub positif baterai, arus listrik semakin kecil, perubahan komponen tidak berpengaruh pada arus komponen lain, baterai sebagai sumber arus tetap, dan arus menimbulkan adanya beda potensial dari penelitian sebelumnya. Penelitian ini dilakukan dengan tujuan mengembangkan suatu perangkat pembelajaran yang mampu mereduksi miskonsepsi siswa tentang materi rangkaian listrik berdasarkan profil miskonsepsi siswa, dan menurunkan miskonsepsi siswa sesudah diterapkan pendekatan saintifik. Penelitian ini menggunakan desain ADDIE (AnalysisDesign-Develop-Implement-Evaluate).Perangkat dibuat dengan menganalisis KI-KD materi rangkaian listrik.Kemudian disusun perangkat pembelajaran dengan menggunakan pendekatan saintifik.Tahap selanjutnya adalah validasi perangkat pembelajaran.Perangkat pembelajaran yang tervalidasidiujicobakan ke siswa kelas IX B SMP Laboratorium Unesa.Sebelum dan sesudah pelaksanaan pembelajaran saintifik, siswa diberikan 10 soal pretes dan postes yang dilengkapi dengan kolom Certainty of Response Index (CRI) untuk membedakan siswa yang tahu konsep (TK), tidak tahu konsep (TTK), dan miskonsepsi (MK). Jumlah miskonsepsi tiap siswa pada pretes dan postes dianalisis menggunakan uji N-Gain ternormalisasi.Dari hasil penelitian didapatkan kesimpulan bahwa pendekatan saintifik mampu mereduksi miskonsepsi siswa dengan kriteria rendah hingga sedang serta kelayakan dari tiap-tiap bagian perangkat pembelajaran dalam kategori layak dan sangat layak
\end{abstract}

Kata kunci : isi, format, artikel

\begin{abstract}
Previous study found that many misconceptions happened in electric circuit matter. For examples, the electricity current was getting smaller when it was far from the positive pole of battery, component changes did not affect the electricity current of other components, battery as DC source, and current could give potential different. This research was conducted in order to develop a learning set which could reduce student's misconception about electric circuit matter based on the student's misconception profile, and also to decrease the student's misconception after a scientific approach was applied. This research used ADDIE (Analysis-Design-Develop-Implement-Evaluate). The learning set was held by analyzing KI-KD of electric circuit matter and using scientific approach method. The next step was doing learning set validation. The validated learning sets were tested to students of class IX B SMP Laboratorium Unesa. Before and after scientific learning conducting, students were given 10 number of pretest and posttest which were completed with Certainty of Response Index (CRI) colomns to differentiate students who knew concept (TK), did not know concept (TTK), and had misconception (MK). The number of misconception of each students in pretest and posttest was analyzed using normalized $N$-gain test. The research outcome showed that scientific approach had ability to reduce student's misconception from lower criteria to middle criteria and also the appropriate for each learning sets were in suitable and the most suitable criteria.
\end{abstract}

Keywords: content, format, article. 


\section{PENDAHULUAN}

Berbagai macam upaya telah dilakukan pemerintah untuk membangun kemajuan pendidikan di Indonesia.Namun, yang diperbaiki dan diperbaharui adalah sistem pendidikan yaitu berupa perubahan kurikulum, serta perbaikan dalam hal kompetensi pengajar, namun jarang bertitik tolak pada kesulitan memahami konsep pelajaran yang dialami siswa sebagai objek pendidikan [1]. Karena siswa sendiri yang mengkonstruksikan pengetahuan dan konsep-konsep yang telah disepakati oleh para ahli, tidak mustahil siswa akan memiliki pemahaman yang salah dalam mengkonstruksi. Kadang-kadang konsep awal yang telah dibangun siswa tidak sesuai dengan konsep ilmiah yang sudah disepakati oleh para ahli.Keadaan demikian disebut dengan miskonsepsi. Miskonsepsi tersebut biasanya sulit diatasi karena siswa cenderung mempertahankan konsep awal ini secara kokoh [2].

Dari berbagai macam penelitian mengenai rangkaian listrik, ditemukan berbagai macam miskonsepsi.Miskonsepsi mengena rangkaian listrik seperti semakin jauh dari kutub positif sumber, semakin kecil arus listrik, jadi sebagian arus diserap dalam lampu dan resistor, jika ada komponen yang ditambah, hanya arus sesudah komponen tersebut yang dipengaruhi, tetapi besar arus sebelum posisi komponen sama dengan semula, arus terbagi sama setiap cabang pada rangkaian paralel, jika ada lampu dalam rangkaian seri atau paralel yang dicabut, beda potensial tempat lampu yang kosong dan kabel yang keluar dianggap nol, Arus listrik dikonsumsi lampu, sehingga di akhir aliran arus menjadi kecil, terangnya lampu dipengaruhi spesifikasi lampu bukan daya disipasi, dan sebagainya.

Merubahmindset siswa mengenai konsep rangkaian listrik yang telah diajarkan dan dipahami sebelumnya tidaklah mudah.Pengubahan miskonsepsi untuk menjadi konsep ilmiah yang benar tidak lepas dari proses berpikir yang disebut sebagai konflik kognitif. Metode pengelolaan konflik kognitif bagi guru dan siswa merupakan hal sangat penting dalam pembelajaran karena konflik kognitif dapat mengarahkan pada hasil yang destruktif (miskonsepsi) maupun konstruktif [3]. Oleh karena itu, sulit bagi seorang guru untuk mengubah prakonsepsi siswa yang salah melalui metode ceramah, tanpa melalui proses belajar yang melibatkan siswa secara aktif mencari solusi dari konflik kognitifnya [4].

Di tahun 2014, pembelajaran harus sesuai dengan landasan kurikulum 2013.Kurikulum 2013 menekankan pada dimensi pedagogik modern dalam pembelajaran, yaitu menggunakan pendekatan ilmiah.Pendekatan ilmiah (scientific approach) dalam pembelajaran sebagaimana dimaksud meliputi mengamati, menanya, menalar, mencoba, membentuk jejaring untuk semua mata pelajaran.Dengan pendekatan saintifik, pembelajaran menjadi berpusat pada siswa.

Berdasarkan uraian di atas, maka dilakukan penelitian untuk mengembangkan suatu perangkat pembelajaran yang mampu mereduksi miskonsepsi siswa tentang materi rangkaian listrik berdasarkan profil miskonsepsi siswa, dan menurunkan miskonsepsi siswa sesudah diterapkan pendekatan saintifik.

\section{METODE PENELITIAN}

Penelitian ini merupakan penelitian pengembangan dengan model ADDIE (Analysis-Design-Develop-Implement-

Evaluate). Perangkat dibuat dengan menganalisis KI-KD materi rangkaian listrik.Kemudian disusun perangkat pembelajaran dengan menggunakan pendekatan saintifik.Tahap selanjutnya adalah validasi perangkat pembelajaran.Perangkat pembelajaran yang tervalidasidiujicobakan ke siswa kelas IX B SMP Laboratorium Unesa. Sebelum dan sesudah pelaksanaan pembelajaran saintifik, siswa diberikan 10 soal pretes dan postes yang dilengkapi dengan kolom 
Certainty of Response Index (CRI) untuk membedakan siswa yang tahu konsep (TK), tidak tahu konsep (TTK), dan miskonsepsi (MK). Jumlah miskonsepsi tiap siswa pada pretes dan postes dianalisis menggunakan uji N-Gain ternormalisasi.

Penelitian berlangsung selama bulan Maret-Oktober 2014.Sampel yang digunakan adalah kelas IX-B SMP Laboratorium Unesa yang berjumlah 15 siswa.Pretes dan postes sama-sama berjumlah 10 soal yang dibuat dengan indikator yang sama. Berikut ini adalah indikator sumber miskonsepsi soal pretes dan postes.

Tabel 1 Kisi-kisi soal

\begin{tabular}{|l|l|l|}
\hline No & $\begin{array}{l}\text { Sumber } \\
\text { Miskonsepsi }\end{array}$ & No Soal \\
\hline 1 & $\begin{array}{l}\text { Model Konsumsi } \\
\text { Arus }\end{array}$ & 1,2 \\
\hline 2 & $\begin{array}{l}\text { Penambahan/pengura } \\
\text { ngan sebuah } \\
\text { komponen tidak } \\
\text { mempengaruhi arus } \\
\text { komponen yang lain }\end{array}$ & $3,4,7,8,10$ \\
\hline 3 & $\begin{array}{l}\text { Baterai sebagai } \\
\text { sumber arus tetap }\end{array}$ & $5,6,7,8,9$, \\
\hline 4 & $\begin{array}{l}\text { Arus dapat } \\
\text { menghasilkan } \\
\text { tegangan }\end{array}$ & 7,9 \\
\hline 5 & Model lain & 10 \\
\hline
\end{tabular}

\section{HASIL DAN PEMBAHASAN}

Pada tahap analisis dilakukan analisis terhadap kurikulum.Sesuai perkembangan pendidikan di Indonesia saat ini, maka kurikulum yang dipakai sebagai acuan pengembangan perangkat pembelajaran adalah Kurikulum 2013.Analisis kurikulum dilakukan dengan menganalisis kompetensi inti serta kompetensi dasar sebagai dasar penyusunan perangkat pembelajaran.Dari analisis tersebut kemudian diputuskan untuk mengangkat materi rangkaian listrik pada SMP kelas IX, dengan kompetensi dasar sebagai berikut.
1.1 Mengagumi
keteraturan
dan
kompleksitas ciptaan Tuhan tentang

aspek fisik dan kimiawi, kehidupan dalam ekosistem, dan peranan manusia dalam lingkungan serta mewujudkannya dalam pengamalan ajaran agama yang dianutnya.

2.2 Menghargai kerja individu dan kelompok dalam aktivitas sehari-hari sebagai wujud implementasi dalam melaksanakan percobaan dan melaporkan hasil percobaan

3.6 Mendeskripsikan karakteristik rangkaian listrik, transmisi energi listrik, sumber-sumber energi listrik alternatif (termasuk bioenergi), berbagai upaya dalam menghemat energi listrik, serta serta penggunaan teknologi listrik di lingkungan sekitar.

4.6 Melakukan penyelidikan untuk menemukan karakteristik rangkaian listrik, serta hubungan energi listrik dengan tegangan, kuat arus dan waktu pemakaian.

Setelah materi ditentukan, kemudian dilakukan analisis konsep.Analisis konsep dilakukan untuk menyusun isi perangkat pembelajaran yang mencakup Silabus, RPP, LKS, Buku Siswa, Tes, dan Lembar Penilaian.

Tahap selanjutnya adalah tahap desain.Pada tahap desain, dibuat perangkat pembelajaran sesuai hasil analisis.Perangkat pembelajaran yang dibuat memperhatikan pendekatan saintifik dalam pembelajaran dan kebutuhan untuk mereduksi miskonsepsi pada materi rangkaian listrik.

Tahap selanjutnya adalah develop atau pengembangan yang dibagi dalam 2 tahapan, yaitu telaah dan validasi. Setelah seluruh perangkat ditelaah hingga mencapai aturan kurikulum 2013 serta memperhatikan pendekatan saintifik dalam pembelajaran dan kebutuhan untuk mereduksi miskonsepsi pada materi rangkaian listrik oleh dosen ahli, perangkat divalidasi untuk dinilai kelayakannya.Hasil validasi dari dosen ahli adalah sebagai berikut. 
Tabel 2 Hasil validasi komponen perangkat pembelajaran

\begin{tabular}{|l|l|l|l|}
\hline $\begin{array}{l}\text { N } \\
\text { o }\end{array}$ & $\begin{array}{l}\text { Perangka } \\
\text { t }\end{array}$ & $\begin{array}{l}\text { Perse } \\
\text { ntase }\end{array}$ & $\begin{array}{l}\text { Katego } \\
\text { ri }\end{array}$ \\
\hline 1 & Silabus & $83 \%$ & $\begin{array}{l}\text { Sangat } \\
\text { layak }\end{array}$ \\
\hline 2 & RPP & $72 \%$ & Layak \\
\hline 3 & LKS & $83 \%$ & $\begin{array}{l}\text { Sangat } \\
\text { layak }\end{array}$ \\
\hline 4 & Buku & $91 \%$ & $\begin{array}{l}\text { Sangat } \\
\text { layak }\end{array}$ \\
\hline 5 & LP Sikap & $90 \%$ & $\begin{array}{l}\text { Sangat } \\
\text { layak }\end{array}$ \\
\hline 6 & $\begin{array}{l}\text { LP } \\
\text { Pengetahu } \\
\text { an }\end{array}$ & $86 \%$ & $\begin{array}{l}\text { Sangat } \\
\text { layak }\end{array}$ \\
\hline 7 & $\begin{array}{l}\text { LP } \\
\text { Keterampi } \\
\text { lan }\end{array}$ & $78 \%$ & Layak \\
\hline \multicolumn{2}{|l|}{ Rata-rata } & $83 \%$ & $\begin{array}{l}\text { Sangat } \\
\text { Layak }\end{array}$ \\
\hline
\end{tabular}

Tahap berikutnya adalah implementation.Pada tahap ini dilakukan pretes, uji coba perangkat dengan pelaksanaan pembelajaran pendekatan saintifik, dan postes di kelas sampel.Pada pelaksanaan pembelajaran, hanya satu langkah yang tidak terjalani secara lengkap yaitu menyimpulkan hasil pebelajaran dikarenakan waktu yang kurang.Hasil pretes dan postes pada tiap soal dapat dilihat pada Gambar 1.

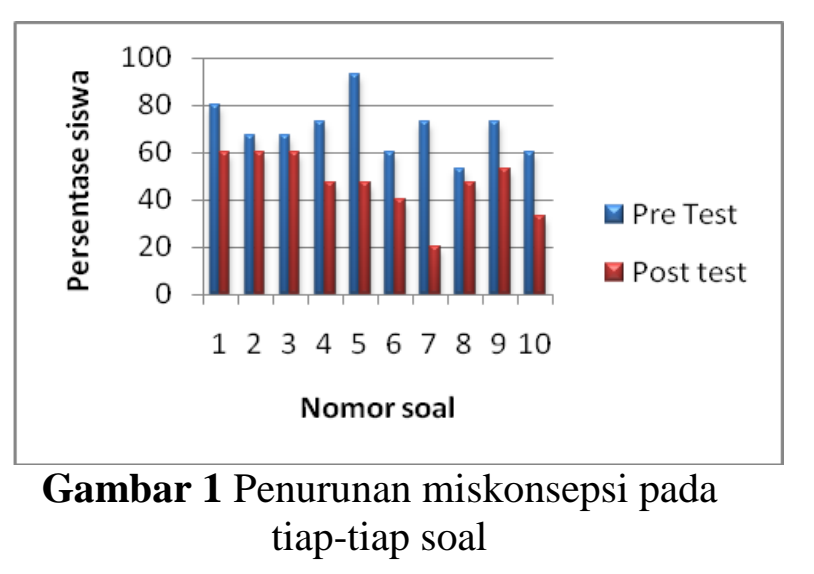

Grafik di atas menjelaskan bahwa terjadi penurunan tingkat miskonsepsi siswa pada materi rangkaian listrik dari nilai pretest dan postest. Penurunan terbesar terjadi pada soal nomor 5 dengan nilai pretest $93 \%$ menjadi $47 \%$ dan soal nomor 7 dengan nilai pretest $73 \%$ menjadi nilai postest $20 \%$. Sedangkan penurunan terkecil terjadi pada soal nomor 2 dan 3 tentang pengaruh besar hambatan terhadap kuat arus listrik yang mengalir pada suatu rangkaian seri, dan soal nomor 8 tentang pengaruh dicabutnya salah satu di antara dua lampu yang disusun secara paralel.Dari data ini didapatkan bahwa pendekatan saintifik mampu menurunkan miskonsepsi siswa pada materi rangkaian listrik pada kriteria rendah hingga sedang.

\section{PENUTUP \\ Simpulan}

Berdasarkan hasil analisis data penelitian,dapat disimpulkan bahwa perangkat pembelajaran dalam kategori layak untuk lembar penilaian dan RPP serta sangat layak untuk lembar penilaian pengetahuan, lembar penilaian sikap, silabus, LKS, dan Buku Siswa serta pembelajaran saintifik mampu mereduksi miskonsepsi siswa pada kriteria rendah hingga sedang

\section{Saran}

Setelah melakukan tahap dan proses penelitian, maka peneliti memberikan saran yang dimaksudkan untuk dipertimbangkan dalam penelitian selanjutnya. Beberapa saran peneliti antara lain:

1. Perlu disediakan sarana dan prasarana penunjang proses pembelajaran menggunakan PhETSimulation, yaitu berupa komputer/laptop, software PhET, sebelum dilaksanakan pembelajaran.

2. Perlu adanya training atau pelatihan terlebih dahulu tentang penggunaan media PhETSimulation.

3. Disarankan untuk melakukan penelitian dengan materi pelajaran yang berbeda.

4. Disarankan untuk pembuatan instrumen tes diagnostik miskonsepsi diberikan pilihan alasan, sehingga interpretasi 
miskonsepsi hasil pretes dan postes lebih akurat.

\section{DAFTAR PUSTAKA}

[1] Sudibyo, Imam. 2013. Profil Konsepsi Hukum Newton Dan Kecakapan Berpikir Kritis Mahasiswa Angkatan 2012 Kelas Internasional prodi Pendidikan Fisika FMIPA Universitas Negeri Surabaya. Skripsi Fisika FMIPA Unesa
[2] Ibrahim, Muslimin. 2012. Konsep, Miskonsepsi, dan Cara Pembelajarannya. Surabaya: UNESA University Press.

[3] Kim, Yeounsoo et al. 2006. Students' Cognitive Conflict and Conceptual Change in a Physics by Inquiry Class. Journal of American Institute of Physics 0-7354-0311- 02/06.

[4] Berg, E.V. 1991. Miskonsepsi Fisika dan Remediasi. Salatiga: Universitas Kristen Satya Wacana press. 